吐血, 下血を伴った胃癌症例の検討

東京医科歯科大学第 1 外科

羽生＼cjkstart丕ティラウッ・クーハプレマ

越智 邦明 竹下 公矢 砂川 正勝

\title{
STUDY ON THE CASES OF GASTRIC CANCER WITH HEMATOEMESIS AND MELENA
}

\section{Hiroshi HABU, Thiravud KHUHAPREMA, Kuniaki OCHI, Kimiya TAKESHITA and Masakatu SUNAGAWA}

The First Department of Surgery, Tokyo Medical and Dental University, School of Medicine

胃癌切除例のうち吐血, 下血を主訴とする43例を出血群と呼び, 臨床病理学的所見と治療成績につ いて非出血群314例之の比較検討を試みた。出血群では早期癌の頻度は $16 \%$ で, 非出血群の $31 \%$ に比べ て低いが $(\mathrm{p}<0.05)$ ，癌巣の大きさ，リンパ節転移，stage，脈管侵襲については差を認めなかった。 出血群では胃上, 中部の癌が合計 $82 \%$ を占め, 非出血群の $58 \%$ に比べて多く $(\mathrm{p}<0.01)$, 出血群の $49 \%$ に胃全摘も乙くは噴切が行われている. 出血のため緊急手術が行われた 7 例のすべてに何らかの合併 症を認め，手術死亡は 2 例（29\%）とさわめて高く，遠隔成績む不良であった。

緊急手術の際は患者のリスクと癌の進行度を考虑し, 慎重に術式を選ぶべさである。

索引用語：胃癌出血，胃癌緊急手術

\section{はじめに}

胃癌症例のうちで吐血, 下血を主訴とするものは $7.3 \sim 17 \%$ 程度といわれ(1) 4), 集団検診なと゚で無症状の まま発見される胃癌が増えつつある現在，このような 出血例の頻度はますます低下寸るすのと思われる.

吐血, 下血が一過性で自然に消失したり, 保存的治 療で止血され，待機的手術を扣こならことができた場 合には, 手術成績, 術後合併症発現率のいずれをとっ ても，一般の胃癌手術の成績と大差ない上らに思われ る.しかしながら止血が困難で, 術前検査が不十分な まま緊急手術が行われた場合, 術後合併症の頻度は高 く, 十分な切除, 郭清が行われないため非治窑切除に 終ることも少なくない。

今回は胃癌顕出血例の臨床病理学的特徵ならびに治 療成績を知る目的で, 非出血例との比較検討を試みた。

$<1984$ 年 10 月 17 日受理 $>$ 別刷請求先: 羽生 丕 T113 東京都文京区湯島 1-5-45 東京医科電科 大学第 1 外科

\section{1. 研究対象と方法}

昭和 47 年 1 月より，56年12月までに教室で切除され た胃癌657例のうち, 吐血, 下血の既往を認めた症例は 48例 (7.3\%) であった。このらち胃，十二指晹潰煌を 合併した 3 例と多発胃癌 2 例を除外し，残る 43 例を出 血群と呼んで研究対象とした，出血の既往のあった日 から手術までの期間は, 短いものでは即日, 長いもの では 2 年に拉よび，平均值は 3 力月，中央值は 42.5 日 であった。一方，昭和 52 年以降に切除された単発胃癌 のうち, 出血例を除く 314 例を非出血群と呼び比較の対 照とし, 両群の臨床病理学的特徵ならびに治療成績を 検討した.

統計的処理は主として $x^{2}$ 検定, $\mathrm{t}$ 検定により，累積 生存率の計算は Life table method ${ }^{5}$ によった。

\section{2. 成}

1）年齢，性別

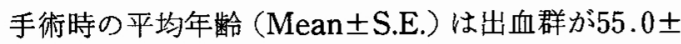
1.9歳, 非出血群は58.6 0.7 歳で差を認めなかった。 男女比をみると, 出血群では3.3：1で, 非出血群の 
2.0：1 に比べ男性に多い傾向がみられたが, 有意差は 認められなかった。

2）癌巣の大きさと肉眼形態

癌巣の最大径 $(M e a n \pm$ S.E.) は出血群では6.1 00.4 $\mathrm{cm}$, 非出血群では $5.6 \pm 0.2 \mathrm{~cm}$ で差を認めなかった。

癌の肉眼型別頻度を表 1 に示す。進行癌については 両群の Borrmann 型別頻度に差を認めなかった。早期 癌の肉眼型についてみると，出血群ではわずか 7 例に 過ざないが，いずれも IIc もしくはIII型の陥凹型早期 癌であった。 また Borrmann 5 型に分類した 3 例も IIc もしくはIII型の陥凹型早期癌類似の進行癌であっ た。

\section{3）占居部位（表 2）}

癌の占居部位別の頻度をみると出血群では A $16 \%$, M 49\%, C 33\%, CMA 2\%であり，非出血群ではA 36\%, M 37\%, C 21\%,CMA 6\%であった。すなわち出 血群では非出血群に比べて $\mathrm{A}$ 領域の癌が少なく, M, C, CMA よ゙胃の上，中部を占める癌が多い傾向が認め られた $(\mathrm{p}<0.01)$.

表 1 肉眼形態

\begin{tabular}{|c|c|c|}
\hline Borrmann分類 & 出 血 群 & 非出血群 \\
\hline ）型 & 0 & $9(4 \%)$ \\
\hline 2 型 & $8(22 \%)$ & $51(24 \%)$ \\
\hline 3 型 & $20(56 \%)$ & $99(46 \%)$ \\
\hline 4 型 & $5(14 \%)$ & $35(16 \%)$ \\
\hline 5 型 & $3(8 \%)$ & $21(10 \%)$ \\
\hline 合 & $36(100 \%)$ & $215(100 \%)$ \\
\hline
\end{tabular}

B. 早期雷癌

\begin{tabular}{|c|l|c|}
\hline 肉 眼 型 & 出血群 & 非出血群 \\
\hline I、Ila & O & $9(9 \%)$ \\
\hline Ilb & 0 & I ( 1\%) \\
\hline IIc、III & $7(100 \%)$ & $69(70 \%)$ \\
\hline 混 合 型 & 0 & $19(20 \%)$ \\
\hline 合 計 & $7(100 \%)$ & $98(100 \%)$ \\
\hline
\end{tabular}

表 2 占居部位

\begin{tabular}{|c|c|c|cc|}
\hline & \multicolumn{2}{|c|}{ 出 血群 } & \multicolumn{2}{|c|}{ 非出血群 } \\
\hline A & 7 & $(16 \%)$ & 114 & $(36 \%)^{*}$ \\
\hline M & $21(49 \%)$ & & $116(37 \%)$ & \\
C & $14(33 \%)$ & $(84 \%)$ & $66(21 \%)$ & $(64 \%)$ \\
CMA & $1(2 \%)$ & & $17(6 \%)$ & \\
\hline 計 & 43 & $(100 \%)$ & 313 & $(100 \%)$ \\
\hline
\end{tabular}

大・小弯, 前・後壁別の占居部位の頻度については 両群の間に有意差を認めなかった。

4) 組織型と深達度

両群の癌の組織型別頻度を表 3 に示す，乳頭腺癌 (pap)，高分化型ならびに中分化型管状腺癌（tub 1な らびに tub 2）を便宜上分化型癌と呼び，低分化腺癌 （por），印環細胞癌（sig）および膠様癌（muc）を低分 化型癌と呼ぶならば，両群ともこれらの割合はほぼ 半々で差を認めなかった。

癌の深達度をみると，表 4 に示すように出血群では 早期癌が $16 \%$, 進行癌が $84 \%$ であり, 非出血群では早 期癌が $31 \%$, 進行癌が $69 \%$ であった。 寸なわら出血群 では非出血群に比べて進行癌が多い傾向が認められた $(\mathrm{p}<0.05)$.

\section{5）リンパ節転移}

組織学的なリンパ節転移の程度をみると，出血群で は $\mathrm{n}_{0}$ 拉よび $\mathrm{n}_{1}$ がともに $33 \%, \mathrm{n}_{2}$ が $19 \%, \mathrm{n}_{3}$ が $15 \%$ であ り，非出血群では $\mathrm{n}_{0}$ が $41 \%, \mathrm{n}_{1}$ が $22 \%, \mathrm{n}_{2}$ が $19 \%, \mathrm{n}_{3}$

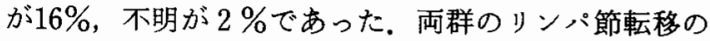
程度については差を認めなかった。

6) 進行程度 (stage)

組織学的にみた進行程度 (stage)を調べると，出血 群では stage I が22\%であり, II, III, IVはいずれる

表 3 組織型

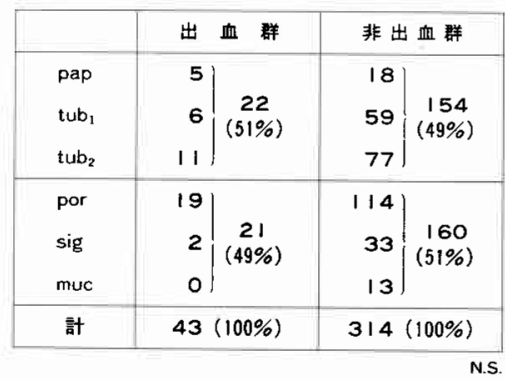

表 4 深達度

\begin{tabular}{|c|c|c|c|c|}
\hline \multirow[b]{2}{*}{$\begin{array}{l}m \\
\mathrm{sm}\end{array}$} & \multicolumn{2}{|c|}{ 出 血 群 } & \multicolumn{2}{|c|}{ 非出血群 } \\
\hline & $\begin{array}{l}5 \\
21\end{array}$ & $\begin{array}{c}7 \\
(16 \%)\end{array}$ & $\begin{array}{l}51 \\
47\end{array}$ & $\begin{array}{c}98 \\
(31 \%)\end{array}$ \\
\hline $\mathrm{pm}$ & 6 & & 33 & \\
\hline $\operatorname{ss} \alpha, \beta$ & 3 & & 29 & \\
\hline$s s \gamma$ & 8 & $\begin{array}{c}36^{*} \\
(84 \%)\end{array}$ & 30 & $\begin{array}{c}215 \\
(69 \%)\end{array}$ \\
\hline se & 13 & & 102 & \\
\hline sei & 6 & & 21 & \\
\hline 計 & 43 & $(100 \%)$ & 313 & $(100 \%)$ \\
\hline
\end{tabular}


26\%であった。一方, 非出血群では stage I が34\%, II

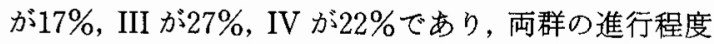
別頻度に差は認められなかった。すすおち胃癌出血例 は必ずしも stage の進んだ症例ばかりでなく， stage I やIIなどあまり進行していない症例の中にも見出さ れた。

\section{7）脈管侵襲}

両群のリンパ管侵襲の程度をみると出血群では $\mathrm{y}_{\mathrm{o}}$ が16\%, $\mathrm{l}_{1}$ が23\%, $\mathrm{ly}_{2}$ が33\%, $\mathrm{ly}_{3}$ が28\%であり, 非出 血群ではそれぞれ $28 \% ， 26 \% ， 25 \% ， 21 \%$ で有意差を 認めなかった。

また静脈侵襲については，出血群で $\mathrm{v}_{0} か ゙ 46 \%, \mathrm{v}_{1}$ が $30 \%, v_{2}$ が $19 \%, v_{3}$ が $5 \%$ であり，非出血群ではそれぞ れ $51 \% ， 23 \% ， 17 \% ， 9 \% て ゙$ 両群の間にやはり有意差 を認めなかった。

8）手術々式と治癒度（表 5)

手術々式をみると，非出血群では幽門側切除が $65 \%$

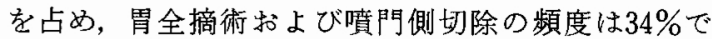
あったのに対して, 出血群では幽門側切除が $51 \%$, 全 摘および噴門側切除が $49 \%$ であった。両群の術式別頻 度に有意差は認められなかったものの，出血群におい てほぼ半数に胃全摘術もしくは噴門側切除が行われた ことは，かなりの高頻度といえよう。

両群に対して行われた手術の治矮度を表 5 に示す。 治㾤切除率は出血群が $68 \%$, 非出血群が76\%で差を認 めなかった。しかし非治癒切除となった原因を検討す ると, 出血群では非出血群に比べて肝転移 $(p<0.01)$ と. 切除断端陽性 $(p<0.02)$ にる非治癒切除例の頻 度が有意に高かった。

9）手術成績

術後 1 カ月以内の直接死亡率は出血群が $7 \%(3 / 43)$
表 5 手術術式

手術術式

\begin{tabular}{|c|c|c|}
\hline & 出 血 群 & 非出血群 \\
\hline 幽門側切除 & $22 \quad(51 \%)$ & $205(65 \%)$ \\
\hline 噴門側切除 & 1 | & 2 \\
\hline 曹 全 摘 & 201 & 1041 \\
\hline 光の他 & 0 & $3(1 \%)$ \\
\hline 計 & $43(100 \%)$ & $314(100 \%)$ \\
\hline
\end{tabular}

治 度

\begin{tabular}{|c|c|c|}
\hline & 出 血 群 & 非出血群 \\
\hline 治切除 & $29(68 \%)$ & $234(76 \%)$ \\
\hline 絶 対 & $24(56 \%)$ & $197(64 \%)$ \\
\hline 相. 対 & $5(12 \%)$ & $37(12 \%)$ \\
\hline 非治滤切除 & $14(32 \%)$ & $74(24 \%)$ \\
\hline$P(t)$ & $7(16 \%)$ & $25(8 \%)$ \\
\hline $\mathrm{H}(+)$ & $6(14 \%)$ & $9(3 \%)$ \\
\hline 断端(十) & $6(14 \%)$ & $14 \backslash 5 \%$ \\
\hline 計 & $43(100 \%)$ & $308(100 \%)$ \\
\hline
\end{tabular}

非出血群が $2 \%$ （6/314）で差を認めなかった。

耐術者のみを対象として累積 5 年生存率 (Mean $\pm S$.

E.)を求めると, 出血群 (40例) では $45.3 \pm 9.9 \%$ であ り, 非出血群 (302例) では $52.2 \pm 3.7 \%$ で, 両群の予 後に有意差を認めなかった，対象を治澺切除例に限っ ても，出血群 $(27 \%)$ の 5 年生存率は $63.6 \pm 11.7 \% て$ あり，非出血群（229例）は69.7士4.3\%でやはり差を 認めなかった。

10）緊急手術例の検討

吐血，下血のために緊急手術が必要であった 7 例を 提示する．その概略は表 6 亿示すとうりである．平均 年齢は57.7歳（最高75歳. 最低30歳）で男女比は 5 ： 2 であった。

表 6 胃癌出血による緊急手術例

\begin{tabular}{|c|c|c|c|c|c|c|c|c|c|c|c|}
\hline No. & 年.性 & $\begin{array}{c}\text { 術前输血 } \\
(\mathrm{ml})\end{array}$ & 占居部位 & 肉眼型 & 皿管露出 & 術式 & 治痖度 & 深達度 & 組織型 & 赫後合併症 & 予 \\
\hline 1 & $75 \hat{\alpha}$ & (十)量不明 & A小 & Bor.3 & $?$ & 幽切 & 非治痖 & sei & por & 䋖合不全 & 32日術死 \\
\hline 2 & $48 \hat{~}$ & $=$ & M嵝 & Bor.2 & $(-)$ & 幽切 & 治 療 & pm & por & 胸 & 3 月病死 \\
\hline 3 & $50 \hat{\delta}$ & $(-)$ & $\mathrm{CM}$ 小前後 & $\begin{array}{l}\text { 隻行型 } \\
\text { 型 }\end{array}$ & $(+)$ & 全摘 & 治 㦂 & ss $\gamma$ & por & 䋖合不全 & 4 年 3月生存 \\
\hline 4 & 30 우 & 2. 000 & C 後 & Bor.3 & $(+)$ & 全摘 & 治 滤 & $\mathrm{pm}$ & $t_{u b}$ & 䋖合不全 & | 年11月監死 \\
\hline 5 & 74 우 & 1.800 & $\mathrm{AM}$ 小前後 & Bor.2 & $(+)$ & 幽切 & 治 郜 & $\mathrm{pm}$ & tub $_{2}$ & 脳出 血 & 3 日術死 \\
\hline 6 & $60 \hat{\delta}$ & 200 & CM前 & Bor.2 & $(+)$ & 全摘 & 治 㓡 & $\mathrm{pm}$ & por & 肝 障害 & 3年0月生存 \\
\hline 7 & $67 \hat{o}$ & 1.600 & CM小 & Bor.2 & $(+)$ & 全墒 & 非治虑 & se & pap & 維合不全 & 3 月癌死 \\
\hline
\end{tabular}




\section{A. 臨床経過}

吐血, 下血が起こってから緊急手術までの日数をみ ると, 出血の当日に手術が行われたものが 4 例, 2 日 目が 2 例, 9 日目が 1 例であった. 手術前に緊急内視 鏡が行われたすのは 2 例に過ざないが，このうち 1 例 では潰瘍底よりの動脈性出血が確認され, 速やかに手 術が行われている（症例 No. 6).

手術術式については 4 例に胃全摘術が，他の 3 例に 幽門側部分切除が行われている。肝転移や腹膜播種を 認めた症例 No. 1, No. 7を除く 5 例に対してリンパ 節郭清が行われている．組織学的な治瘾度を検討する と 3 例が絶対治癒切除, 1 例が相対治瘾切除, 3 例が 絶対非治癮切除であった。非治癒切除となった理由は $\mathrm{P}_{3}, \mathrm{H}_{3}$ が 1 例, $\mathrm{H}_{2}$ が 1 例, ow (+) が 1 例であった。

緊急手術直後の検查データを見ると, 血清総蛋白量 は平均 $5.4 \mathrm{~g} / \mathrm{dl}$ (最高 $6.5 \mathrm{~g} / \mathrm{dl}$, 最低 $4.3 \mathrm{~g} / \mathrm{dl}$ ), アルブミ ン值は平均 $3.0 \mathrm{~g} / \mathrm{dl}$ （最高 $3.9 \mathrm{~g} / \mathrm{dl}$, 最低 $2.6 \mathrm{~g} / \mathrm{dl}$ ) であ り，いずれも待機的手術が行われた症例に比べると低 い值であった。

緊急手術例の全例に何らかの術後合併症を認めた。 4 例に縫合不全が発生し, この内 1 例が死亡している (症例 No. 1)。立た 1 例は手術直後に脳内出血を起こ し 3 日目に死亡している(症例 No. 5).この 2 例を手 術死亡とすると, その比率は $29 \%$ でわめて高頻度で あった。残る耐術者 5 例のうち, 非治瘾切除の 2 例を 含む 3 例がその後癌死している. 残る 2 例は術後 5 年 8 カ月および 4 年の現在健在である（症例No. 3 拉よ びNo. 6).

\section{B. 肉眼的・病理組織学的所見}

緊急手術時の肉眼的所見をみると, 癌が $C$ もしくは $\mathrm{CM}$ 領域を占めるものが 7 例中 4 例（57\%）と最も多 く, 肉眼型ではボルマン 2 型 4 例, 3 型 2 例, IIc + III 型 1 例といずれも癌巣内に潰湟を伴ら型であった。記 載の明らかな 6 例中 5 例に括いて, 潰瘍底に出血源と 思われる露出血管を認めた。

組織型は低分化腺癌 (por) が 4 例と最も多く, 中分 化型管状腺癌 (tub 2) が 2 例, 乳頭状腺癌 (pap) が 1 例であった。癌の深達度は $\mathrm{pm}$ が 4 例之最も多く ss $\gamma$, se 拉よびseiが沶の打の 1 例であり，むしろ深達 度の比較的浅い症例が多かった。リンパ節郭清が行わ れた 5 例について転移の程度をみると, $\mathrm{n}_{0} か ゙ 2$ 例, $\mathrm{n}_{1}$ が 1 例, $\mathrm{n}_{2}$ が 2 例であり, stage 分類は stage I が 2 例, II が 1 例，IIIが 2 例，IVが 2 例であった。リンパ管侵 襲は比較的高度なるのが多く，7例中 6 例が陽性であ
り，静脈侵襲は 7 例中 3 例において陽性であった，癌 組織中の間質量の多室については中間型が 5 例と最も 多く, 髄様型 1 例, 硬性型 1 例であった。

\section{4. 考 察}

上部消化管出血の原因として胃癌の占める割合は Bogoch $^{6}$ によれば1.2〜2.7\%に過ざないという。胃癌 が比較的多い我が国に括いてもその頻度は 6.9 22.3\%程度で, 胃潰瘍に比べればその頻度は少な いようである ${ }^{7) ~}$. 長尾ら ${ }^{101}$ は胃出血の原因疾患につ いて，消化性潰瘍が59.1\%で最も多く，胃癌と胃炎が ともに14.6\%で2 位であったと報告している.

一方，胃癌の中で吐血，下血を主症状とするものは

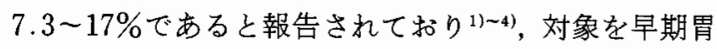
癌だけに限っても, その頻度は $9 \%$ 程度と言われてい $3^{11122}$. 今回われわれの症例では胃癌出血例の頻度は 胃癌切除総数の $7.3 \%$ で, 従来の報告に比べ低い,傾向に あるが，集団検診などで無症状のまま発見される症例 が増えたこともその一因と思われる。

年齢と出血の関係について佐藤ら ${ }^{11}$ は, 若年層に顕 出血例が多いと報告しているが，われわれの成績では 出血群と非出血群の平均年齢に有意差を認めることは できなかった．性別に関しても従来の報告1)と同様に, 一般の胃癌に比べて特別の傾向を認めることはできな かった.

癌巣の大きさと出血の頻度について, 西ら 2)は癌が 大きくなるほど出血例の頻度も増加すると述べてい る. 一方, 藤田 (3) $^{3}$ は大型の癌よりも直径が $2 \sim 5 \mathrm{~cm}$ 程 度の癌に出血例が多く, しかも大量出血をさたするの が多いと報告している，われわれの成績では，出血群 と非出血群の癌の平均最大径に有意差を認めることは できなかった。

癌の肉眼型についてみると, 板野ら ${ }^{11)}$ や佐々木ら ${ }^{12)}$ の報告と同様に, 出血群の早期癌あるいは早期癌類似 進行癌は全例が陥凹型のものであった。進行癌のボル マン分類については出血群と非出血群との間に有意差 は認められなかったものの, 出血群ではボルマン 1 型 は 1 例もなく，ボルマン 2 型， 3 型など明らかな潰場 を有するものが約 $80 \%$ 占めていた。これらのことか ら胃癌の出血の原因は癌巣の潰瘍化と関係が深いもの と思われ，とくに緊急手術が行われた 7 例では全例が 潰煌形成性の癌であり，らち5 例に乱いて潰瘍底の一 部に明らかな露出血管を認めている。

出血性胃癌の占拠部位を大 - 小弯, 前・後壁別にみ ると, その頻度は一般の胃癌と差がないという報告が 
多い122．これをCMA 別にみると，特別な傾向を認め ないといら報告むあるが3)，胃上部の癌に出血例が多 いという報告も少なくない(1)2．われわれの症例でも， 出血群では非出血群に比べて $\mathrm{A}$ 領域の癌が少なく, C 領域やM領域の癌が多い傾向が認められた。このこと は，切除にあたって胃全摘を必要とするものが多いこ とを示しており，事実われわれの経験した緊急手術例 7 例のうち 4 例 $(57 \%)$ に全摘術が行われている。こ のことが, 後に述べるように, 出血性胃癌の緊急手術 において合併症発見率ならびに手術死亡率が高い一因 になっていると思われる。

癌の深達度と出血の関係については, 今回の成績と 同様に，深達度が深くなる活ど出血例の頻度が増すと いら報告が多いが3113)，早期胃癌からの出血例も報告 されている ${ }^{11) 12) . ~}$

癌の組織像と出血の関係について, 梶谷 ${ }^{14)}$ 胃癌出 血は髄様癌に多く硬性癌に少ないと述べている．藤田 ら゙は組織型では分化型の癌に大量出血をきたすすの が多く，間質量については䯑道様型のものに出血例が多 い傾向があると報告している。しかし，われわれの経 験した緊急手術例 7 例では間質量が中間型のものが 5 例で最す多く，髄様型之硬性型がそれぞれ 1 例ずつと， 上記の傾向を裏付けることはできなかった，

岡島 ${ }^{15)}$ (胃癌出血の機序につき, 癌組織内に新生増 殖した毛細血管が癌組織の破壊によって損傷されるた めに起こり，一般に渗出性の慢性出血であるが，化膿 性炎症などが加わるとその部は急速に壊死に陥り，破 壊され，太い血管まで損傷されて大出血が起こるので あろうと述べている.中西融は血管造影の所見から，胃 癌の中心では周辺部に比べて血管の発達が比較的粗 で，血流減少から壊死脱落を起こしゃすいのではない かと推測している。

北島 ${ }^{177}$ は, 露出血管をともなら胃潰瘍に比べて, 胃癌 では太い粘膜下層血管の露出をみることがまれなた め, 大量出血が少ないのであろらと推測している。こ れらのことが，後に述べるように，胃癌出血例のなか で緊急手術を要するものが比較的少ないことの理由と 思われる。一方, 佐及木ら ${ }^{12)}$ は早期胃癌出血例の検討か ら, 早期癌では癌組織そのものからの出血はむしろ少 なく, 癌の存在しない潰煌底部分から出血したと思わ れるものが多く，この点ではむしろ良性潰湟の出血に 似ると述べている。

手術成績について佐藤ら らびに治癒切除率はその他の群に比べて低いが，これ
は顕出血例に stage の進んだものが多いためで, 出血 そのものの影響ではなかららと述べている。われわれ の成績では出血群と非出血群の切除率に有意差を見出 すことはできず，組織学的 stage についても両群の間 に差を認めなかった。しかし，非治癒切除となった理 由を検討すると, 出血群では非出血群に比べて肝転移 と切除断端陽性例の頻度が有意に高く，とくに後者に ついては出血群に胃上部の癌が多いことに起因すると 思われた。

待機手術例屯含めた出血例全般の合併症発現率や手 術死亡率については，一般の胃切除例に比べて高率で あるといら意見 ${ }^{11}$ と，差を認めないという意見 ${ }^{13)}$ とが ある。 今回の成䋶では，直接死亡率は出血群が $7 \%$, 非出血群が $2 \%$ で有意差は認められず，遠隔成績につ いても, 出血群の累積 5 年生存率は $45.3 \%$ で, 非出血 群の $52.2 \%$ に比べて差を認めなかった。

緊急手術の頻度について佐久間ら ${ }^{13}$ 恃全胃癌症例の $1 \%$ ，顕出血例の $7 \%$ であったと報告している，われ われの経験でも緊急手術例は同時期の胃癌切除総数 657 例の $1.1 \%$, 出血群 43 例の $16.3 \%$ に当り, その頻度 は一般に低いようである。

緊急手術の適応について，長尾ら ${ }^{10)}$ は胃癌に限らず ショック症状を呈する胃出血例のらち, $400 \sim 1,000 \mathrm{ml}$ の急速輸血を行ってもショック状態の改善しない症例 を緊急手術の対象とすると述べて打り，佐藤ら 血後24時間しても止血しない場合を緊急手術の絶対適 応とし，近い過去に大量出血の既往がある場合を比較 的適応とすると述べている。われわれはできうる限り 保存的治療を行い, 待機手術に持ち込むよらに努めて いるが，急性出血の反復する症例や，内視鏡的観察で 明らかな動脈性出血を認める例に対しては緊急手術の 適応と考㝋ている(4).

緊急手術例の手術成績ならびに予後の不良なことは すべての報告に一致するところである。佐久間ら ${ }^{131}$ は 緊急手術に際し, 胃全摘ないしは噴門側切除江合併切 除を加齐た 8 例中 6 例 (75\%) が縫合不全や後出血で 死亡したと報告し，全摘や噴門側切除に合併切除を加 觉ることは極力避けるべきであると述べている，間島 $ら^{18)}$ は緊急手術例10例中 6 例 $(60 \%)$ に術後合併症が発 生し，この内 5 例 $(50 \%)$ が死亡したと報告し，緊急 手術例の成績が悪い理由として高齢者が多いこと，進 行癌が多いこと, 大量出血による全身状態の悪化など を挙げ、リスクによっては胃切除を行わずに止血だけ を目的とした術式も選択されるべきであると述べてい 
る.

われわれの症例です緊急手術例 7 例の全例に縫合不 全その他の合併症が起こり，2 例 (28.6\%) が死亡し ている．これらの症例で手術直後に測定した血清総蛋 白量, アルプミン值がいずれもきわめて低值であった ことは，創傷治癒の上からる不利な状態にあることを 示すものと思われる。これに加兄て胃上部癌の頻度が 高く, 胃全摘や膵脾合併切除など侵襲の大きな手術が 要求されることが成績不良の原因であろう。

これら緊急手術例の予後をみると, 耐術者 5 例のう ち 3 例が癌死して括り, 緊急手術例恃機手術例に比 べて遠隔成績の上からも不利であると思われる，その 理由として, 術前検査が不十分なため, 良性潰瘍の出 血として手術されたり，手術侵襲の軽减を計るあまり， 切除範囲やリンパ節の郭清などが不十分になるためで はないかと思われる，胃癌出血例に対して緊急手術を 行ら際の術式の選択にあたっては，安全性と根治性と の折り合いに苦虑することが多い，個々の症例のリス クと癌の進行度を考党，時には二期的切除も考慮に入 れつつ慎重に切除範用，リンパ節郭清の程度，合併切 除の有無などを決定するべきであろう。

$$
\text { まとめ }
$$

胃癌症例のうち吐血, 下血を主訴とする顕出血例 43 例をとり上げ, 非出血例と比較しつつその臨床病理学 的特徵ならびに治療成績を検討し，以下の結論を得た。

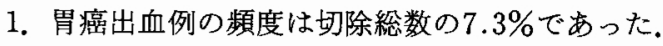

2. 出血群では非出血群に比べ進行癌の頻度が高い が，癌の大きさ，リンパ節転移， stage, 脈管侵襲の頻 度については両群間に差を認めなかった。

3. 出血群の癌は胃の上, 中部を占めるものが多く, その約半数に胃全摘もしくは噴閏側切除が行われてい る.

4. 治癒切除率, 直接死亡率, 5 年生存率については 両群の間に差を認めないが，出血群では肝転移ならび に口側断端陽性による非治瘜切除例が多い傾向が認め られた。

5. 緊急手術例の合併症発現率ならびに手術死亡率 はきわめて高く，遠隔成績は不良であった。

以上の成績より, 胃癌出血例に対しては保存的治療 のら光待機手術を行らことを基本方針とすべきであ
り，止むをえず緊急手術を行ら場合は，患者のリスク と癌の進行度を考虑に入れ，慎重に手術方針を決定す べきであろら。

\section{文献}

1）佐藤寿雄, 佐久間晃, 小野寺紘一ほか：胃癌の出 血・外科診療 $14: 397-404,1972$

2) 西 満正, 加治佐隆, 野村秀洋注か：上部消化管大 量出血の手術めぐる問題点一胃癌一. 臨外 32 ： 999-1004, 1977

3）藤田佳宏, 小島 治, 竹中 温致加: 吐血・下血を 主訴とした胃癌症例の検討。日消外会誌 11 ： 1051-1056, 1978

4) 羽生 丕, 毛受松寿: 悪性腫場による急性腹症·特 集急性腹症, 消化器外科セミナー, 9 , 東京, へる 寸出版, 1982, p302-318

5) Cutler SJ, Ederer F, Bethesda BS: Maximum utilization of the life table method in analyzing survival. J Chron Dis 8 : 699-712, 1958

6) Bogoch A: Hematoemesia and melena In : Gastroenterology vol 1. Third edition. Edited by HL Bockus. Philadelphia, Saunders, 1974, p763-826

7) 村上忠重, 桜井 哲, 山広 昇汪か：上部消化管出 血の統計的観察。外科 $28: 556-563,1966$

8）吉井隆博：消化管出血の病理. 竹本忠良編，叶血， 下血の臨床, 東京, 中外医学社, 1979, p32-50

9) 城所 仂: 胃癌と出血 (早期胃癌を含を). 竹本忠 良編, 吐血, 下血の臨床, 東京, 中外医学社, 1979, p188-193

10）長尾房大, 池内準治, 成川恒夫：胃出血患者の病態 と集計的観察. 外科 $30: 453-461 ， 1968$

11）板野 聡, 大西信行, 小淵欽哉：吐下血を呈して発 見された早期胃癌の検討. 臨外 $36: 1137-1142$, 1981

12）佐々木明, 桑原正知, 武田 功：吐血, 下血を主訴 とした早期胃癌症例の検討. 日消外会誌 15 ： 601-607, 1982

13）佐久間晃, 渡部忠信, 佐藤寿雄：胃癌加らの大量出 血の治療. 外科治療 $28: 674-680,1973$

14）梶谷鐶，山田肃：胃癌に打ける出血, 臨外 $12: 233-242,1957$

15）岡島邦雄：胃癌出血,外科 $39: 1233-1240,1977$

16）中西宏行：切除胃壁に分布する血管の研究. 日外 会誌 $72 ： 1682-1710,1971$

17）北島正樹, 相馬 智：胃癌に合併する吐血. 1. 検 査のすすめ方と手術適応。外科 $43: 354-359$, 1981

18）間島 進, 藤田佳宏：胃癌からの出血ならびにそ の対策. 外科診療 21：797-801，1979 